\title{
Biztos Kezdet Gyerekház program
}

\section{Koscsóné Kolkopf Judit}

Józsefvárosi Egyesített Bölcsődék, intézményvezető

Az olvasó képet kaphat egy olyan komplex, a korai intervenciót szolgáló program Magyarországon való meghonosodásáról, amelyben a gyermek szülőjével együtt áll a középpontban. Megismerheti a józsefvárosi Biztos Kezdet program és a Biztos Kezdet Gyerekház megvalósulásának előzményeit, állomásait, szakmai sarokpontjait, müködését, tapasztalatait. A tanulmány érinti a jelenlegi szabályozást és annak közeljövőben történő változásait, valamint a szolgáltatás országos kiterjesztésének további ütemét. Bemutatja a gyermekek korai fejlesztésével, a családok szociokulturális környezetének támogatásával a gyermekszegénység csökkentésének és a gyermeki esélyek növelésének lehetőségeit.

Kulcsszavak: biztos kezdet, helyi komplex program, gyermek-család, esély, együttmüködés

\section{Bevezető}

„Úgy tetszik, hogy jó helyen vagyunk itt.”

(nagyszalontai népdal)

A XX. század utolsó éveiben a fejlett nyugati országok gyermekvédelmi gyakorlata jelentős változáson ment keresztül. A kisgyermekkori ellátások különféle formái kerültek a figyelem középpontjába (Herczog, 2008). Míg korábban a gyermek veszélyektől való - mindenáron történő (pl. gyermek kiemelése a családból) - megvédése volt a cél, addig a 1980-90-es években a gyermekek érdekében ezt felváltotta a család, mint legkisebb társadalmi egység megerősítésének igénye (Bányai, 2004).

1999-ben Angliában e jogi-szemléletbeli-szakmai paradigmaváltás hatására a gyermekszegénység problémájának megoldására született meg az a válasz, amelyben kidolgozták a bármilyen hátrányban szenvedő gyermekek számára azt a preventív illetve terápiás programot, amelynek célja a korai képességfejlesztés. E program a hátrányos helyzetű térségekben lépcsőzetes kiépítéssel, az egész gyermekvédelmi intézményrendszert érintve a kormány által messzemenően támogatott formában indult. Mára már több mint 3600 helyen működik (Sure Start Programiroda, 2002, 1-5. füzetek) (www.surestart.gov.uk).

A program a Sure Start, azaz a Biztos Kezdet elnevezést kapta.

\section{A Biztos Kezdet Program Magyarországon}

\section{Társadalmi elözmények}

Magyarországon a 1989-es rendszerváltást követő társadalmi-gazdasági változások egymást erősítve sok családot s rajtuk keresztül sok gyermeket kedvezőtlenül érintettek. Az alacsony iskolai végzettségű szülők esetében különösen megnőtt a kockázat a szegénység és a társadalmi perifériára való sodródás terén. A szakma itthon e helyzet feloldására kereste és találta meg a Sure Start = Biztos Kezdet programot, mint az egyik lehetséges megoldást. 
Arra a kérdésre pedig, hogy miért is szükséges Magyarországon a program, a - gyermekek védelméről és a gyámügyi igazgatásról szóló 1997. évi XXXI. törvény (Gyvt.) által megfogalmazott - gyermeki és szülői jogok érvényesülésének részleges teljesülése a válasz.

\section{Érvek a Biztos Kezdet program mellett}

A Gyvt. 6. § (1), (4) bekezdése szerint: „a gyermeknek joga van a testi, értelmi, érzelmi és erkölcsi fejlődését, egészséges felnevelkedését és jólétét biztositó saját családi környezetében történő nevelkedéshez” „...joga van ahhoz, hogy a fejlödésére ártalmas környezeti és társadalmi hatások, valamint az egészségére káros szerek ellen védelemben részesüljön".

- A rendszerváltás után felhalmozódott társadalmi hátrányok - a társadalmi törvényszerüség okán - évről évre újratermelődtek és sajnos az eltelt 25 év alatt sem igazán csökkentek.

- A vidéki, kis lélekszámú településeinken és a nagyvárosaink elszegényedett, gyakran elszigetelt városrészeiben a hátrányok halmozottan, egymást felerősítve jelentkeznek. Itt a szegénység okozta problémákat még a gazdasági és földrajzi izoláció is terheli. Ezeken a területeken felnövekvő új generációk kitörése a szegénységi csapdából szinte lehetetlenné vált.

- A kistelepüléseken a gyermekes családokat támogató rendszerek - gyakorta a szakemberhiány és egyék okok miatt - minimális szinten müködnek (Bányai, 2006; Szomor, 2006). A nagyvárosi izoláció által kitermelt diszfunkcionálisan müködő, vagy atomizált vagy egyszülős családok gyermekei sem mindig jutnak hozzá a városokban egyébként jól kiépített és az őket megillető szolgáltatásokhoz. Az ilyen esetekben lehetőség sincs arra, hogy felismerhető legyen a fejlődési lemaradás, így pont a rászoruló gyermekek esetében maradnak el a 0-3 éves korban leghatékonyabb és szükséges korai fejlesztések.

- Sajnálatos módon a gyermekeket nevelő családoknál a szegénység, az alacsony iskolázottság, a pszichés/anyagi nélkülözés, a kirekesztettség, az ehhez párosuló egészségkárosodások olyan környezeti és viselkedési mintákat termelnek ki, amelyek nem vagy alig biztosítják megfelelően a felnövő gyermek optimális fejlődésének lehetőségét. E szociokulturális környezetbe született gyermekek sok esetben lemaradnak kortársaiktól szociális és intellektuális szegénységben felnőve jutnak el a kötelező óvodáig, majd az iskoláig.

- A szociális szakma álláspontja szerint azért szükséges a Biztos Kezdet program, mert a fentiekben bemutatott társadalmi hátrányok megszüntetését, az „átörökítés megtörését az első években kell megkezdeni”. (Darvas, 2011, 10.). A program egyik fő feladata a gyermeket váró leendő szülőkkel és a már gyermeket/gyermekeket nevelő szülőkkel való együttmüködés e cél elérése érdekében.

„A hátrányos helyzetü és a halmozottan hátrányos helyzetü gyermeknekjoga van ahhoz, hogy fokozott segítséget kapjon a fejlődését hátráltató körülmények leküzdéséhez és esélyeinek növeléséhez" (Gyvt. 6. § (2a)).

- A hátrányos helyzetü gyermekek számára az esélyegyenlőség előmozdításának elengedhetetlen feltétele az egyenlő hozzáférés biztosításán túl, olyan támogató lépések, szolgáltatások tervezése, megvalósítása, amelyek csökkentik a meglévő hátrányaikat, javítják a majdani iskolai sikerességüket. Az esélyegyenlőség biztosítása és előmozdítása nem összemosható, egymással nem helyettesíthető, jól elkülöníthető fogalmak, amelyek egyben egymást kiegészítő célokat jelölnek meg. Az esélyegyenlőség biztosítása olyan általában passzív cselekedet, amely valamit kinyit, lehetővé tesz az adott védett csoport számára is. Az esélyegyenlőség előmozdítása aktív cselekedet, amelynek eredménye, hogy 
a védett csoport tagjai valóban élni tudnak a számukra nyújtott lehetőségekkel. Esélyegyenlőség érvényesüléséről csak akkor beszélhetünk, ha mindkét cél egyszerre teljesül, az adott védett csoport tényleges résztvevővé válik.

- A gyermekek kiszolgáltatottak, szükségük van a felnőttek védelmére, gondoskodására, szeretetére. Biztonságra van a szükségük a túléléshez, az egészséges fejlődéshez, az örömteli gyermekkorhoz és ahhoz, hogy a társadalom későbbi tevékeny résztvevői lehessenek. Mindehhez a jogot a gyermekek számára az ENSZ Gyermekjogi Egyezménye (1989) is deklarálja.

- „A hazai Biztos Kezdet Program esélyegyenlőségi program” is. (Szilvási, 2011. 31-32. o.) Elsődleges célja a „lehető legjobb esély biztosítása a készségek és képességek kibontakoztatásához, a lehető legkorábbi életkorban, azon gyerekek számára, akik a legnagyobb szegénységben élnek.” (1195/2009.(XI.20.) Kormányhatározat a „Legyen jobb a gyerekeknek!” Nemzeti Stratégiáról,)

„A gyermeknek joga van ahhoz, hogy segítséget kapjon a saját családjában történö nevelkedéséhez, személyiségének kibontakoztatásához, a fejlödését veszélyeztető helyzet elhárításához, a társadalomba való beilleszkedéséhez, valamint önálló életvitelének megteremtéséhez"(Gyvt. 6. § (2)).

- „Amennyiben eltérés mutatkozik az életkori sajátosságok és az adott egyén fejlődése között, akkor beszélhetünk nem megfelelő vagy megkésett fejlődésről" (Szomor, 2007. 21.). Létfontosságú a minimális fejlődési zavarral vagy a környezeti okok miatt megkésett, megakadt fejlődéssel, esetleges éretlenséggel született gyermekek esetében a korai felismerés, mert így a folyamatok felzárkóztathatóak lehetnek.

- A gyermek fejlődési ütemét meghatározzák a biológiai és környezeti tényezők. Már csecsemő- és kisgyermekkorban jól felismerhetőek a megtorpanások, lemaradások (Scheer, 2007). A gyermekek későbbi életpályájának sikeres alakulása szempontjából kulcsfontosságú a minél korábbi életszakaszukban nyújtott szakszerű támogatás, mert ez alapozhatja meg az iskolai eredményességet.

- A kisgyermek korai fejlődésének támogatása kétirányú kell, hogy legyen. Egyrészt a gyermekre irányuló közvetlen, másrészt a családra irányuló szülői készségeket, ismereteket átadó közvetett fejlesztés, az együttműködés jegyében.

- A Biztos Kezdet program a családok támogatására épül, hiszen szükséges és kiemelkedően fontos társadalmi érdek a korai beavatkozás a jövő felnövekvő generációja érdekében, és az is egyértelmüen megfogalmazható, hogy mindez a szülőkkel való foglalkozás nélkül nem megvalósítható. A gyermek számára a megfelelő fejlődési környezetet a korai életszakaszában a ,jól működő” család jelenti.

A Gyvt. 12. § (2) bekezdés szerint: „a gyermek szülője jogosult arra, hogy a gyermeke nevelkedését segítő ellátásokról tájékoztatást, neveléséhez segítséget kapjon".

- A Biztos Kezdet Program a hátrányos helyzetű környezetbe telepítve, ott helyben, olyan szolgáltatást biztosít mind a gyermekek, mind a családok számára, amely elősegíti a szociális, érzelmi fejlődésüket, javítja az egészségi állapotukat, fejleszti a nyelvi, kommunikációs, tanulási képességeiket, felkészíti őket az intézményrendszerhez való alkalmazkodásra, erősíti a családot, praktikus életvezetési ismereteket nyújt és képes kialakítani az érintettekből egy egymást támogató, megtartó közösséget (Szomor, 2006).

\section{A korai iskolaelhagyás}

- Magyarországnak az IEA Társasághoz (International Association for the Evaluation of Educational Achievement) való csatlakozása (1968) lehetővé tette az országok oktatási rendszereinek, térben és időben egymástól távoli tanulási teljesítményeknek az összehasonlítását. Csapó Benő A magyar tanulók 
tudása nemzetközi összehasonlításban című tanulmányában írja a következőket „Kiderült, hogy a családi-kulturális tényezőknek nagyobb jelentőségük van, mint annak, hogy hány éves korban kezdődik az iskolai olvasásoktatás, és mennyi ideig tart." (Csapó, 2002)

- Az Európai Unió 2020-ra kitűzött öt stratégiai céljának egyike - amelyet Magyarország is célul tűzött ki -, hogy az évtized végére 10\%-nál kevesebb legyen azon 18-24 éves fiatalok aránya, akiknek nincs befejezett középszintü végzettsége, azaz akik szinte teljesen esélytelenül lépnek be a munkaerőpiacra.

- Az Európai Bizottság 2010-ben készült, a korai iskolaelhagyás mérséklését célzó dokumentuma (EUROPEAN COMMISSION 2010.) alapján azok a fiatalok válnak jóval nagyobb eséllyel a rendszer elhagyóivá, akik:

- „szegény, szociálisan hátrányos helyzetü, alacsony iskolázottságú családi háttérrel rendelkeznek;

- hátrányos helyzetű kisebbségekhez tartoznak (roma származás);

- sérülékenyebb csoportokba tartozók, így az állami gondozottak, tinédzser korban szülővé válók, a sajátos nevelési igényü fiatalok;

- családtagjaikról kell anyagi vagy más értelemben gondoskodniuk;

- alig kötődnek az iskolához - pl. iskolakerülők, bomlasztó magatartásúak, magántanulóvá váltak;

- nincsenek iskolai sikereik, évismétlők".

Az itt felsorolt veszélyeztető tényezők egy része olyan, amely már viszonylag korai életkorban felismerhető, ezért kezelésükre hatékony megoldást jelenthet a mielőbbi preventív és támogató beavatkozások sora.

A Biztos Kezdet Program munkatársai alkalmasak arra, hogy felismerjék a hátrányokat, preventív segítséget adjanak ahhoz, hogy a résztvevő tan-, óvodaköteles korba érő (3-5 éves) gyermekek a veleszületett képességeik optimumát érjék el minden fejlődési területet érintően (mozgás, értelem, érzelem, nyelv és kommunikáció, észlelés), s ezáltal a korai iskolaelhagyást megelőzhessük. A gyermekkor egészét tekintve az is bizonyított, hogy „a korai életkorban történő beruházások hatékony társadalmi befektetésként értelmezhetőek. A közgazdaságtudomány költség-haszon elemzései egyértelműen bizonyították, hogy a kora gyermekkori programok összehasonlíthatatlanul kedvezőbb eredményre vezetnek, fajlagosan olcsóbbak, mint a későbbi életszakaszokat célzó kompenzáló programok" (Darvas, 2011. 9. o.).

\section{A Biztos Kezdet Program adaptálási folyamata}

Az előző részben kifejtett tényezők 2003-ban együttesen vezetettek arra a kormányzati elhatározásra, hogy a Sure Start programot Magyarországon is bevezessék. Az Egészségügyi Szociális és Családügyi Minisztériumban egy munkacsoportot hoztak létre azzal a feladattal, hogy a magyar Biztos Kezdet programot az angol program alapján a magyar sajátosságok figyelembe vételével adaptálják, egy modellkísérletet indítsanak el. Az elkövetkező két év tapasztalata kellett ahhoz, hogy országos szinten terjeszthetővé váljon a kezdeményezés és megalakuljanak az első Biztos Kezdet Klubok, majd hat évvel később a TÁMOP 5.2.2. pályázati konstrukció keretében az első Biztos Kezdet Gyerekházak.

Több éves folyamatként megfogalmazásra kerültek a hazai alapelvek és célok is.

Alapelvek: prevenció, hozzáférés minden érintett számára, nyitott szolgáltatás a helyi igényekre építve, közös szakmai irányelvek, partnerség (szakmaközi és szülőkkel való együttmüködés), univerzális és célzott szolgáltatás, hátrányos helyzetű kistérségekre és települési szegregátumokra (pl.: VIII. kerület Magdolna-negyed) irányultan. 
Célcsoport: 0-5 éves, nagy hátránnyal induló gyermekek. Célok:

„Elsődleges cél a lehető legjobb esély biztositása a készségek, képességek kibontakoztatásához a lehető legkorábbi életkorban, azon gyerekek számára, akik a legnagyobb szegénységben élnek." (Kovács, 2011. 21. o.)

„Hosszú távú célkitüzés egy olyan gyerek- és családbarát szolgáltatási környezet kialakitása országos szinten, amely a szülök partneri bevonása és aktív részvétele mellett koragyermekkorban egyenlő esélyt biztosit a veleszületett képességek kibontakoztatásához, a minél korábbi bölcsődei, óvodai részvételhez, és a sikeres iskolakezdéshez." (Kovács, 2011. 21. o.)

Rész-stratégiai célok is megfogalmazódtak:

A gyermekekkel való rendszeres foglalkozás a szülő bevonásával:

- szociális és érzelmi fejlődés támogatása,

- képesség kibontakoztatása,

- szülő-gyerek kapcsolat erősítése,

- család erősítése, közösség erősítése,

- egészségkultúra fejlesztése,

- a korai iskolaelhagyás megelőzése érdekében.

- A gyermek fejlődésének nyomon követése.

- A gyermekek szürése: fejlődési elmaradások felismerése.

- Azonosított fejlődési zavar felismerését követően a megfelelő szakemberhez irányítás.

- A szülők együttmüködésének megnyerése, támogatása saját erőforrásaik mobilizálásával.

- A gyermek hiányzó kompetenciái megszerzésének segítése.

- A program helyi közösségbe való beillesztése.

- Belső és szakmaközi team-megbeszélések.

- Szakmaközi együttmüködés (Biztos Kezdet Gyerekházak hálózatának Szolgáltatási és Szervezeti Modellje, 2009).

\section{Kronológia}

- 2003-ban a Brit Nagykövetség és az Egészségügyi Szociális és Családügyi Minisztérium közös szervezésében Magyarországon bemutatásra kerül az angliai Sure Start program.

- 2004 januárjában, az országban 6 szerkezetileg és szociológiailag is eltérő településen (Ózd, Csurgó, Örtilos, Vásárosnamény és hat társult települése, Budapest VIII. kerület, Mórahalom) elindul a magyar Biztos Kezdet kísérleti modell.

- 2005: további 2 település (Győr, Katymár) kapcsolódik be a kísérletbe. Szakértői mühely alakul, feladata az országos bevezetés kivitelezése.

- 2006-tól további 52 új program indul el, megjelennek a Biztos Kezdet Klubok.

- 2007: MTA kutatócsoport munkájának köszönhetően megszületik a Gyermekszegénység Elleni Nemzeti Program (www.gyerekesely.hu). A munkacsoport aktív közreműködésével létrejön a „Legyen jobb a gyermekeknek!” Nemzeti Stratégia 2007-2032, melyet az Országgyúlés májusban fogad el. (Az Országgyűlés 47/2007. (V.31.) OGY határozata)

- 2008: A Gyermekszegénység Elleni Nemzeti Program és a Nemzeti Stratégia eredményeként az Új Magyarország Fejlesztési Terv (www.nfu.hu) keretében kiírásra kerül a TÁMOP 5.2.1. „Gyermekesély program országos kiterjesztésének szakmai-módszertani megalapozása és a program kísérése" pályázat.

- 2009: A TÁMOP 5.2.2. projekt (www.nfu.hu) országszerte 36 Biztos Kezdet Gyerekház kialakítására nyújt uniós fedezetet. Köztük szinte az elsők között létrejön a Józsefvárosi Biztos Kezdet Gyerekház is.

- 2009-2013 között összesen országosan 114 Gyerekház nyit kaput. 
- 2012: a TÁMOP 5.2.2. uniós projektet befejező 41 Gyerekház finanszírozása már az e célra elkülönített minisztériumi forrásból történik.

- 2013. január 1-jétől a Biztos Kezdet Gyerekházak működési feltételei - mint gyermekjóléti alapellátás - szakmai jogszabályi szintre emelkednek, azaz beillesztésre kerülnek a gyermekek védelméről és a gyámügyi igazgatásról szóló 1997. évi XXXI. törvénybe. 2013. március 1-től a 15/1998. NM rendeletbe kerülnek bele a szakmai szabályok.

- 2014. január 1-jétől a Biztos Kezdet Gyerekházak müködési finanszírozását már a központi állami költségvetés biztosítja. Első körben 49 Gyerekház kerül befogadásra a finanszírozási körbe a Nemzeti Rehabilitációs és Szociális Hivatal (NRSZH) által 2013. szeptember 16. napjával meghirdetett meghívásos „a Biztos Kezdet Gyerekházat működtető szolgáltatók általános pályázata" alapján három évre 2016. december 31. napjáig szóló Támogatási Szerződés alapján. A feltételeket a 191/2008. (VII. 30.) Korm. rendelet szabályozza és az NRSZH koordinálja. A müködési támogatás mintegy 6,2 millió forint/év szolgáltatásonként.

- 2015-ben az állami finanszírozási körbe további 64 Gyerekház kerül befogadásra.

\section{A Józsefvárosi Biztos Kezdet Program}

\section{A józsefvárosi program helyi társadalmi környezete}

A VIII. kerület-Józsefváros a Főváros egyik központi elhelyezkedésű kicsi (6,85 km2), de a népesség szám tekintetében igen sürün lakott kerülete (1 km²-ren 11131 lakos). Nevét 1977-ben II. József uralkodó után kapta. Lakónépessége 76.250 fő, ebből a 0-17 éves korú gyermekek száma 9122, a 0-5 évesek száma 3234, a 0-2 évesek száma: 1763 fő.

A 9122 gyermek közül 2675 gyermek (29,3\%) olyan szociális körülmények között él, hogy a rendkívüli gyermekvédelmi kedvezményre (RGYK) jogosult. A 0-2 évesek 19 \%-a (340 fő) RGYK-s (forrás: Winszoc adatbázis 2015.03.18.).

A felnőtt lakosság 21 \%-ának sincs középfokú végzettsége. Az aktív lakosok 10 \%-a regisztrált munkanélküli.

A kerület közlekedési csomópont, talán ennek hatására a népesség összetétele is igen változatos. Sok a külföldi betelepedő, a lakosok $20 \%$-a nem magyar nemzetiségü. A lakosok $4 \%$-a vallja magát cigánynak. A lakásállomány $34 \%$-a 40m² alatti. A lakásállomány alacsony minőségét jelzi, hogy a lakások 10\%-a 2011-ben nem komfortos (forrás: KSH 2011. évi népszámlálási adatok).

A kerület területe 11 szocio-ökonómiai egységre, „negyedre” van osztva. A negyedek társadalmi-gazdasági-építészeti-történelmi-kulturális szempontból és a földrajzi elhelyezkedésüknek megfelelően erősen különböznek egymástól.

Társadalmi és környezeti problémákkal a kerület egyik legjobban terhelt területe a Magdolna-negyed (Scheer, 2009). A területen a hátrányos helyzetủ családok koncentrációja magas, a fizikai környezet leromlott, a gazdasági potenciál, a foglalkoztatási helyzet és az iskolázottsági szint tekintetében is itt a legnagyobb a lemaradás. Földrajzilag e negyed szélén Józsefvárosra írt programmal a kerület egyetlen lakótelepének szomszédságában 2009. 09. 15. napján nyitotta meg kapuit a Biztos Kezdet Gyerekház.

A józsefvárosi helyi program holisztikus megközelítésü, mert:

- feltár olyan kérdéseket, mint az egészség, a fejlődés, az étrend, a tisztaság, nyelvi, szociális és kognitív fejlődés, kihangsúlyozva azt, hogy mennyire fontos az anya jólléte a gyermek fejlődése szempontjából; 
- $\quad$ igyekszik fokozni az apák, illetve a partnerek szerepét, mely arra irányul, hogy a lehető legtöbb felelősséget adja a szülők kezébe, építve meglévő erősségeikre, és megadva nekik azt az érzést, hogy irányíthatják a saját életüket és gyermekeik nevelését;

- bátorítja a szülőket, hogy találkozzanak más szülőkkel a szociális támogatottság érzését erősítve és a közösségi életben való részvétel értékeit mutatva;

- a család egészének pszicho-szociális szükségleteit kezeli.

Helyi célok:

- a szociális és érzelmi fejlődés javítása: különösen a szülők és gyermekeik között kialakuló korai kapcsolat támogatása, a családok müködésének segítése, az érzelmi és magatartásbeli nehézségekkel küszködő gyermekek korai felismerése és támogatása;

- az egészségi állapot javítása;

- a gyerekek tanulási képességeinek javítása, a korai iskolaelhagyás megelőzése;

- a nyelvi jártasságok javítása;

- a család és a közösségek erősítése;

- a gyermek családon belüli helyzetének erősítése;

A józsefvárosi Biztos Kezdet Gyerekház egy régi bérház földszintjén $120 \mathrm{~m}^{2}$-es alapterületen, hétfőtől péntekig 8,30-tól 13 óráig térítésmentesen fogadja a VIII. kerületben élő családokat. Havi és heti tervekkel biztosítja a változatos és aktív programokat. A munkaterv a gyermekek erősségeit, esetleges fejlesztendő területeit és a csoport összetételét veszi figyelembe.

Azt azonban, hogy egy adott délelőttön hány és éppen melyik család látogatja meg a Gyerekházat nem ismert előre. A Gyerekházat önkéntesen saját ritmusukban keresik fel a regisztrált vagy az éppen teljesen új családok. Mindezek miatt a program rugalmas, ami munkatársainktól azonnali reagálási képességet kíván.

\section{Múködés, napirend, szolgáltatások (egyedi mutatók, jellemzők, célcsoport, prog- ramok, jó gyakorlat)}

A heti terv fő vezérvonala, hogy a gyermekek testi és szellemi fejlődésének minden szakasza érintett legyen. A hasonló területeket érintő foglalkozások azonos napokra kerülnek, ezzel is erősítve a gyermekekben a rendszerességet, a szülőknek pedig a kiszámíthatóságot.

A Gyerekház tízórai étkezést biztosít (lásd 1. ábra), amellyel az egészséges táplálkozás ösztönzése és a különféle ízek minél természetesebb formában történő megismertetése a cél. Tudatos törekvés, hogy a kínált étel és ital ne csak az étkezés funkcióját töltse be, hanem lehetőséget adjon az evőeszköz, pohár, használatának helyes elsajátítására, széleskörü információt nyújtson a szülők számára az alapanyagok és az érzékszervi tulajdonságok megnevezésével. /íz, illat, színek/. Az étrend a szülőkkel együtt kerül tervezésre és elkészítésre, amely befolyásolja az otthoni étkezési szokásokat és ismeretet ad a takarékos, gazdaságos és esztétikai technikák elsajátítására, a különleges kreatív tálalási módok kitalálására. A gyermekekkel végzett terítés, tálalás a közösen végzett tevékenységek körét bővíti. Az együtt készített étel a közös étkezés, nemcsak szocializációs színtér, nemcsak az étkezési kultúra elsajátításának módja, hanem értelmi, érzelmi, és a finommotorika fejlesztésének is kiváló módja. 


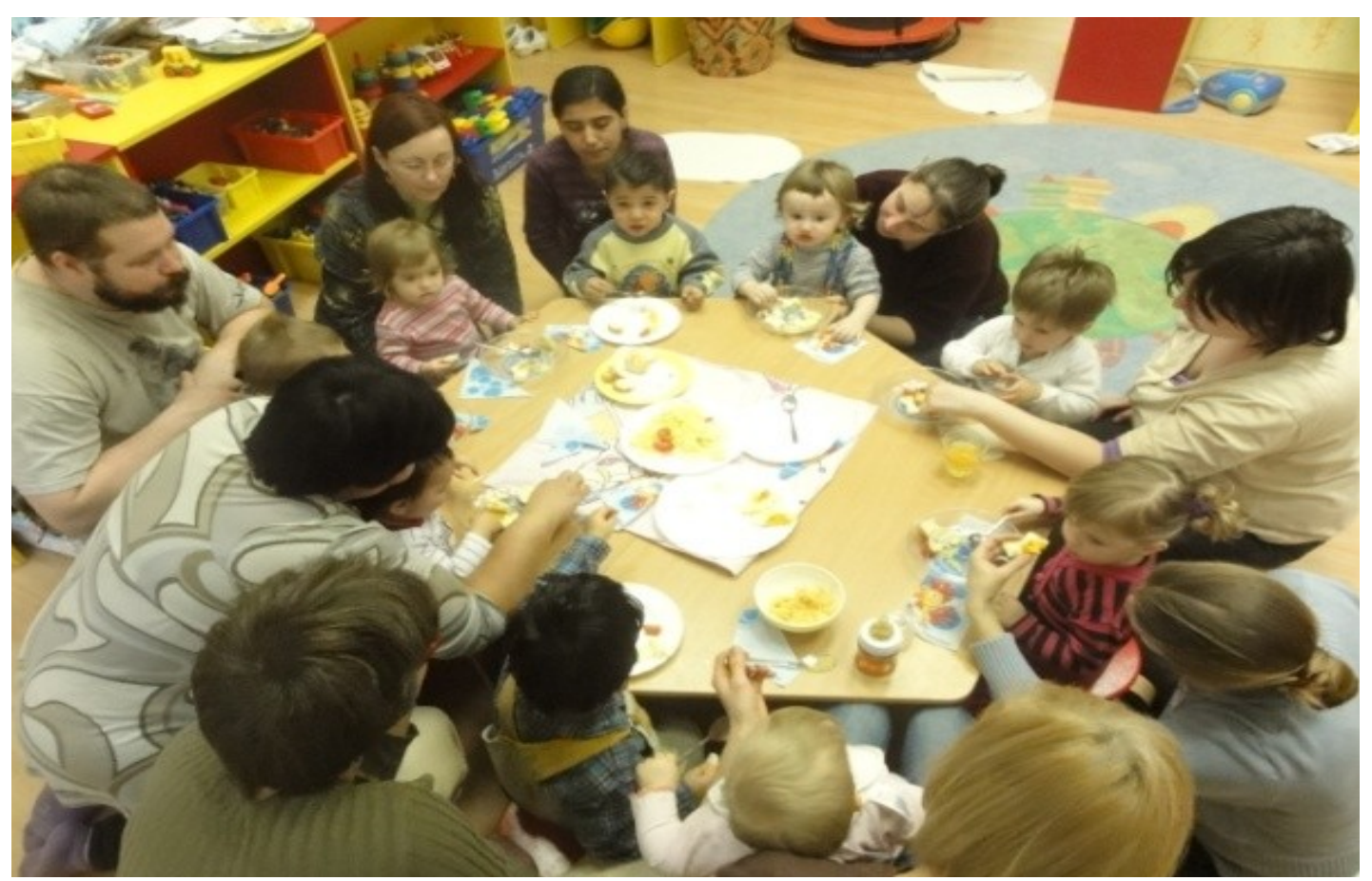

1. ábra: tízórai étkezés (forrás: saját fotó)

\section{Gyerekekre irányuló szolgáltatások}

A Gyerekházba jellemzően a 0-3 éves korú gyermekek járnak, legtöbbjük 2 éves korban a helyi bölcsődébe kerül. A Gyerekház közössége az első olyan szocializációs színtér ahol a gyerekek a kortársakkal találkoznak. A szülök képet kaphatnak gyermekeik erősségeiröl, esetleges gyengeségeiröl. A bizalomteli befogadó légkör lehetőséget ad arra, hogy kérdéseiket, észrevételeiket megoszthassák a Gyerekház dolgozóival.

Gyakran előfordul, hogy pár hónapos babák egyszerre vannak jelen a két és félhároméves gyermekekkel, ezért fontos a korcsoportokra fókuszáló program. Kiemelt az egy év alatti gyermekekre irányuló foglalkozás. Tapasztalat, hogy maguk a szülők nem mindig tudják, hogy "mit lehet kezdeni” a csecsemővel. A ,jó természetü” gyermekeket sokszor és sokáig hagyják feküdni kontaktus kezdeményezése nélkül, a „roszszakat" az idő nagy részében ölben tartják, ezért fontos feladat úgy irányítani a babamama egymásra hangolódását, kapcsolatát, hogy az a gyermek fejlődését erősítse.

A rendszeresség érdekében minden délelött tartalmaz egy 10-20 perces főprogramot:

- Hétfö - az éneklés, mondókázás napja

A játékos éneklés, mondókázás, irányított (lásd 2. ábra). Jelentősége az érzékelés és az érzelmek fejlesztésében van a tapintás, érintés által kiváltott ingerek útján, továbbá fejlődik a gyermekek ritmusérzéke, bővül a szókincse, ezzel is elősegítve az iskolai életben való majdani részvételüket. 


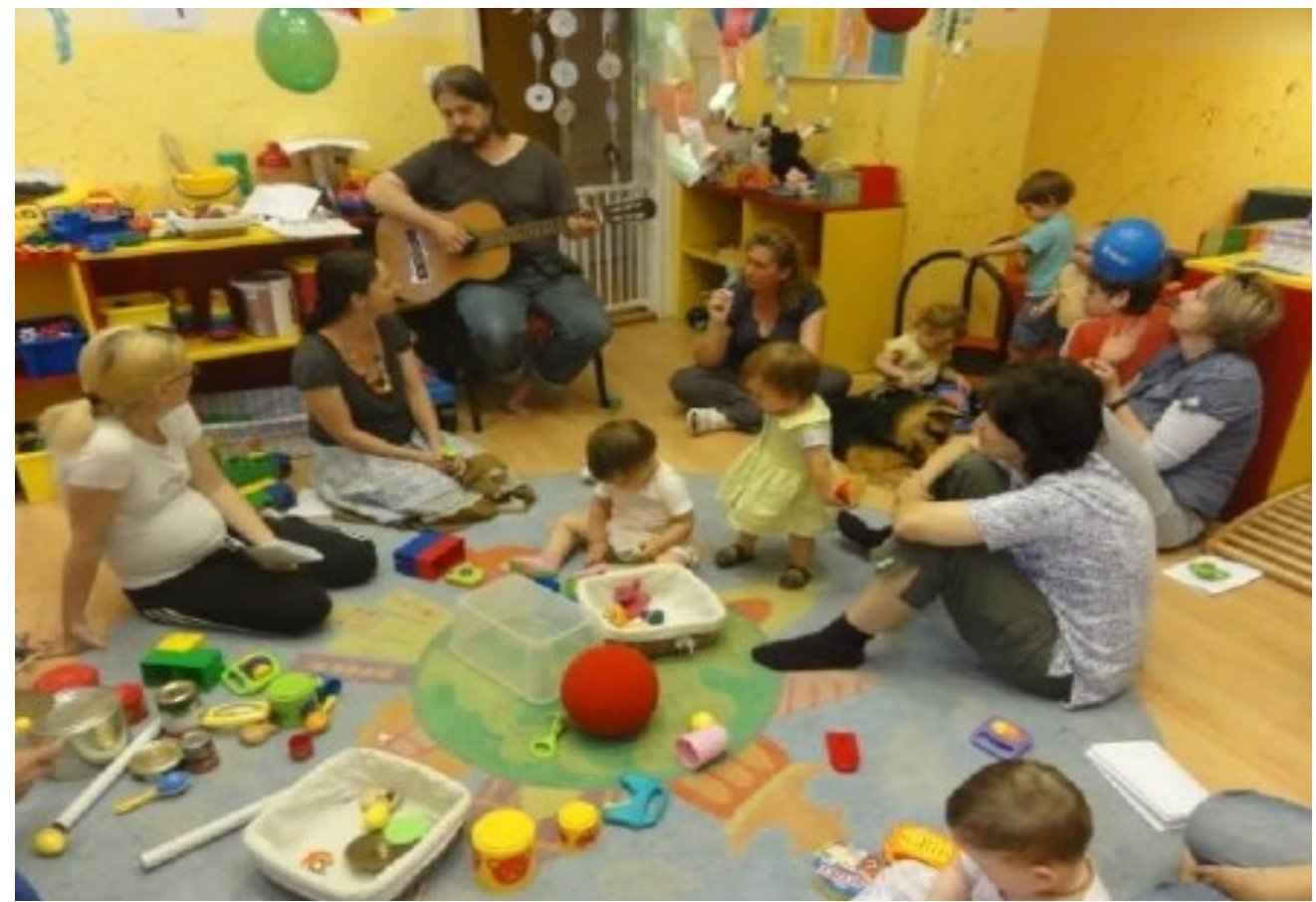

2. ábra: Életkép - énekelés, mondókázás (forrás: saját fotó)

- Kedd - a nagymozgásoké (lásd 3. ábra)

A mozgásfejlesztést rendszeresen járó konduktor segíti, a fejlesztést igénylőknél, az ő szakmai ajánlására a Gyerekház dolgozói együtt a szülőkkel gyakoroltathatják a szakember által meghatározott mozgásformákat a lemaradás minél előbbi „ledolgozása” érdekében.

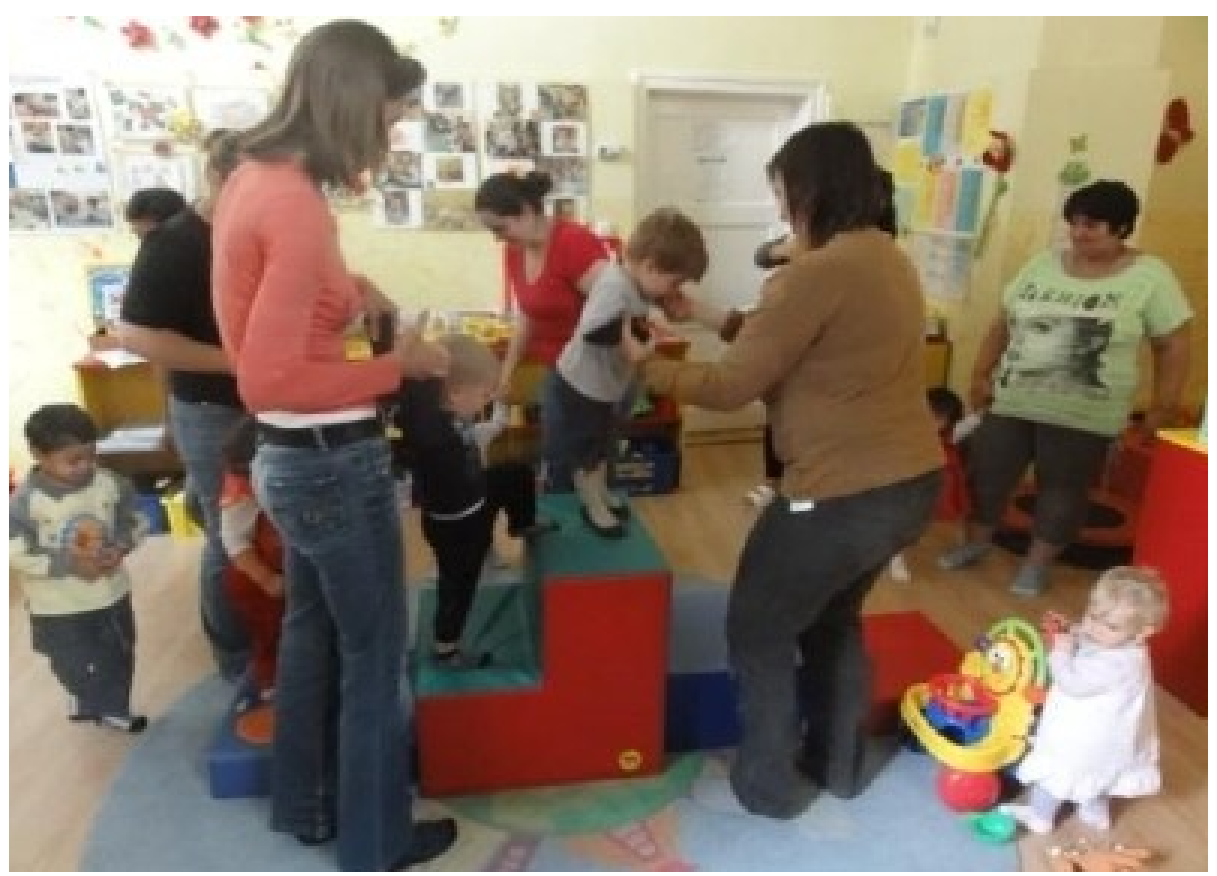

3. ábra: nagymozgásos tevékenység (forrás: saját fotó)

- Szerda - a közös sütés napja, közben éneklés, mondókázás

Egészséges, könnyen elkészíthető és olcsó receptekből készülnek alkotások. Az ételek előkészítése során fejlődik a kézügyesség, szülőgyermek megéli a közös alkotás örömét (lásd 4. ábra). 


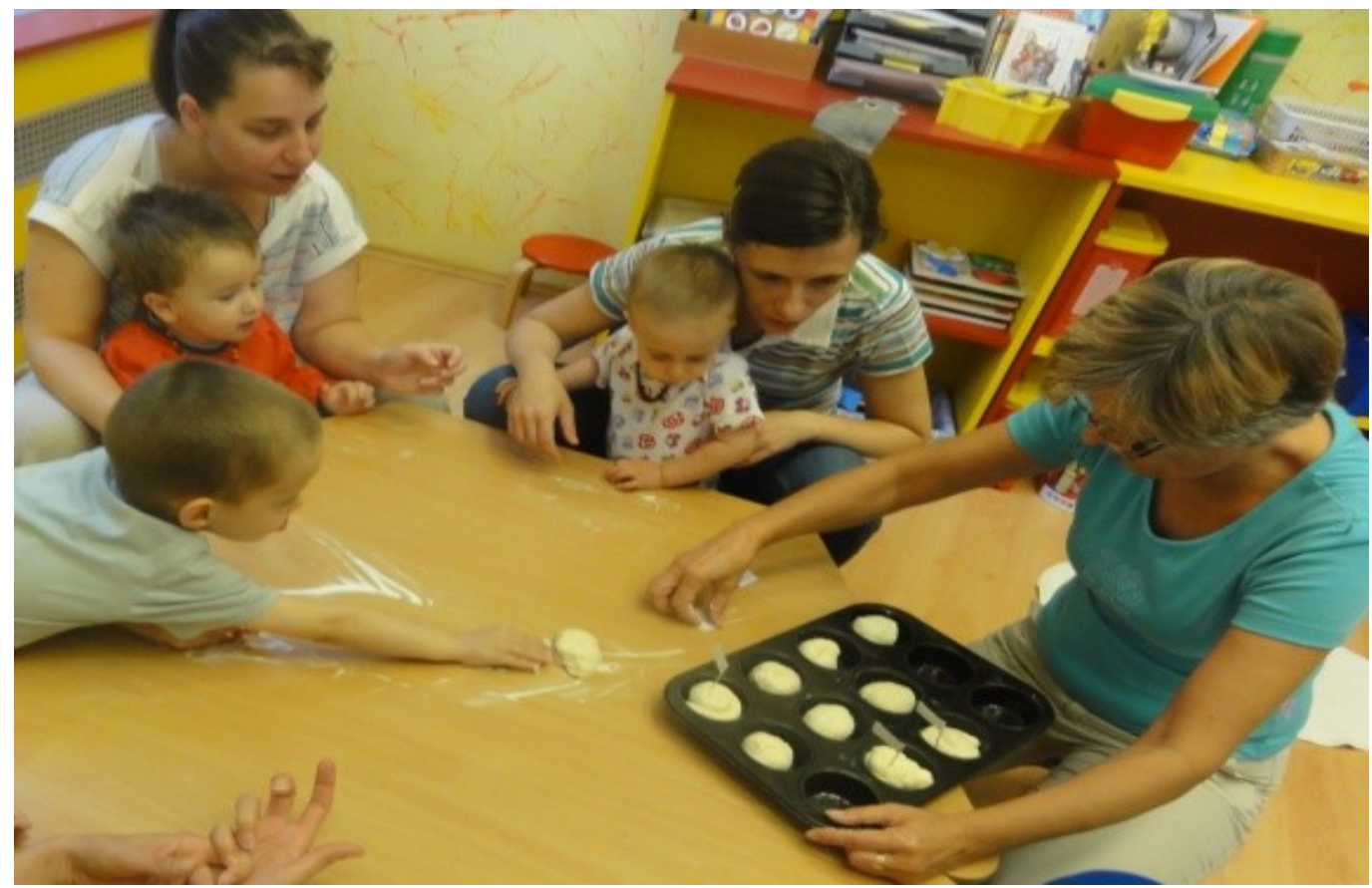

4. ábra: közös sütés-főzés (forrás: saját fotó)

- Csütörtök/Péntek délelőtt - finommotorikát fejlesztő tevékenységeknek, a hagyományok ápolásának, népi játékoknak ad teret

A finommotorikát érintő tevékenységek az alkotás örömén túl, élményt és tapasztalatot nyújtanak a különböző textúrájú és színű anyagok felhasználásával. Információt, számtalan kreatív ötletet adnak az újrahasznosítás, környezettudatosság, játék, különböző az otthon együtt végezhető tevékenységek megvalósítására.

\section{Szülökre irányuló szolgáltatások}

A legtöbb szülő számára központi kérdés „Vajon elég jó szülö-e?”.

Fontos a szülői bizonytalanság csökkentése, a szülői kompetenciájukban való megerősítés, a munkatársunk által megfelelő minta nyújtása. Hangsúlyt fektetünk a szülők önbecsülésének fejlesztésére, mentálhigiénéjük javítására. Mindezek rövid és hosszú távon kihatnak az egész családra.

- Szülőcsoportos foglalkozás, mosási, fürdetési lehetőség, számítógép-használat, ügyintézés:

a gyermeki fejlődéssel együtt járó életkori sajátosságokkal, problémákkal, tapasztalatokkal szembesülve a szülők gyakran tehetetlennek érzik magukat. A rendszeres a beszélgető kör ad keretet a szülők aktuális problémáinak, kérdésinek, nehézségeinek megbeszélésére.

Szakmai együttmüködés:

prevenciós céllal a bölcsőde orvosa egészségügyi, a dietetikusa táplálkozástudományi, a szerződéses konduktor mozgásfejlődéssel kapcsolatos témában csoportos és egyéni tanácsadást nyújt. A késedelmes nyelvi fejlődést eseti megbízás alapján logopédus szakember szúri. Több család is a kerületi védőnők jelzései alapján került a Biztos Kezdet Gyerekházba. Itt találkozhatnak újra, ahol tanácsadást tartanak, a szülőket aktuálisan érdeklő kérdésekről interaktív beszélgetéseket folytatnak.

- Tájékoztatók, kiadványok, hírlevelek: 
negyedévente az orvosi rendelőkben, védőnőknél, bölcsődékben kihelyezett hírlevél hirdeti az aktuális és a közel jövő programjait, ezekre hívjuk fel a figyelmüket.

- Közösségi rendezvények a helyi lakosság bevonásával, jeles napokhoz kapcsolódó hagyományőrző programok:

a közösségi rendezvények is fontos pillérei a Gyerekház működésének. A mindennapok során figyelmet fordítunk a születésnapok, jeles ünnepnapok megtartására. Vannak nagyobb szabású rendezvényeink is - Gyermeknap, Csere-Bere nap, Hétvégi Palánta játszóház, Mikulás rendezvény, Farsang - melyek alkalmat adnak arra, hogy a Gyerekházba nem járó, azt még nem ismerő helyi lakosságot is megszólítsuk, elérjük.

- „Jó gyakorlat” és országosan is egyedülálló program a családi nyaralás Magyarkúton.

A Gyerekház megnyitása óta minden évben, kétszer egy hétre táborozni viszi a családokat. Jelentős ennek az intenzív együttlétnek a közösségformáló ereje. A tábor során a gyermekek számára a Gyerekház mindennapi tematikájának megfelelő programok, a szülők számára esti csoportfoglalkozások, előadások kerülnek megtartásra, melyek ideje alatt a gyermekfelügyelet megoldott.

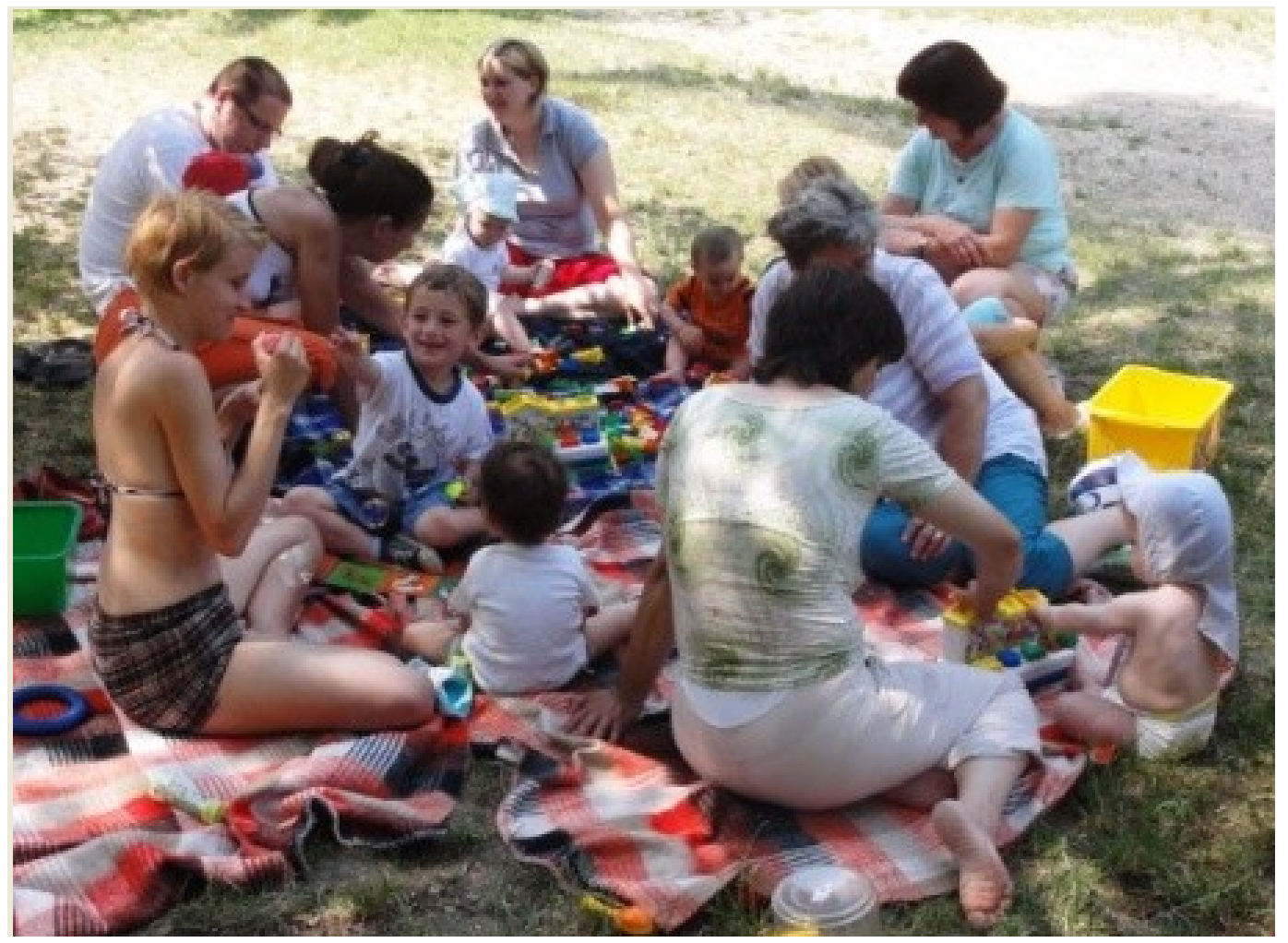

5. ábra: nyári táborozás Magyarkúton (forrás: saját fotó)

\section{A józsefvárosi Biztos Kezdet Gyerekház 5 éves lett}

2014. november 25-én ünnepelte a Józsefvárosi Biztos Kezdet Gyerekház az 5 éves születésnapját. A születésnapi délelőtti program a Gyerekházban zajlott, közös tortafelvágással és beszélgetéssel az ellátott családok és magas rangú vendégek társaságában. A délutáni program során Kerekasztal beszélgetésre került sor, számos szakember társaságában (25-30 szervezettől, 60 fő szakember) a téma a múlt-jelenjövő szakmai megközelítése volt. 


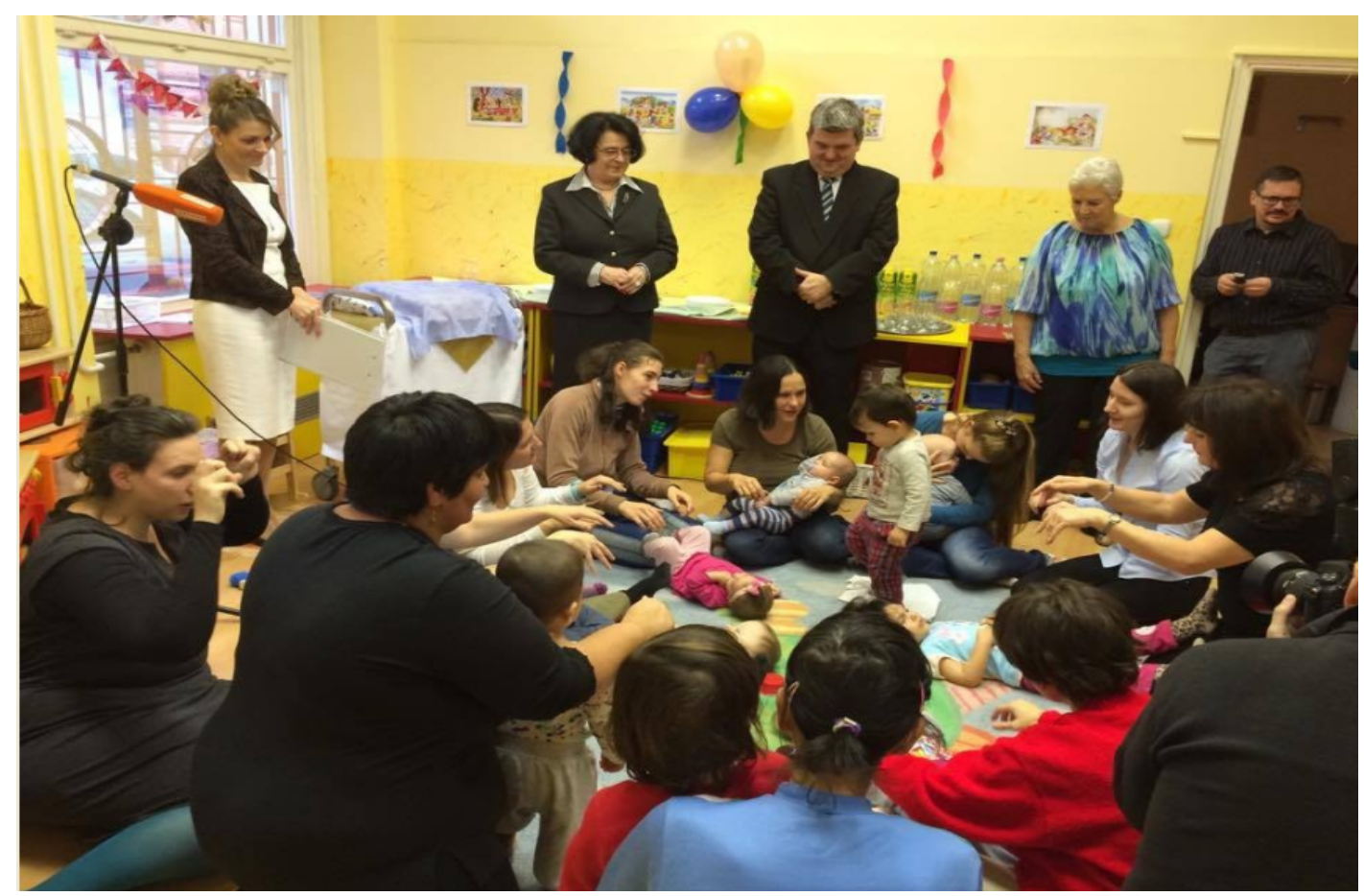

6. ábra: születésnapi délelőtti rendezvény (forrás: saját fotó)

\section{9-2014. évre vonatkozó adatok}

2009. szeptember és 2014. október között a kerületi lakosok összesen 10498 alkalommal vették igénybe a józsefvárosi Gyerekház szolgáltatásait. A Józsefvárosi Biztos Kezdet Gyerekház Dokumentációs Rendszerében regisztrált gyermekek száma: 372 fö, ebből rendszeresen járó gyermek 231 fö. A gyermekekröl Biztos Kezdet megfigyelő lap lett kitöltve, amely a személyes, társas és érzelmi fejlődés, a kommunikáció, nyelvi fejlődés, problémamegoldás, gondolkodás és számolás, a világról alkotott kép, a testi és a kreatív fejlődés állomásait rögzíti 14 szakaszra bontva 6 havonta. Minden esetben kitöltésre kerül a szülök nevelési ismeretei címü kérdőív is (forrás: saját adatbázis).

A kérdőív és a gyermek megfigyelő lapok alapján kerültek kinyerésre a családok szociális helyzetét bemutató alábbi adatok.

A megkérdezettek:

- $26 \%$-a $40 \mathrm{~m}^{2}$ alatti alapterületủ lakásban lakik,

- 23\%-a egyszobás lakásban él,

- $29 \%$-ának volt olyan élménye, hogy nem volt elegendő pénze ennivalóra, 5\%-nak ez az élmény gyakori,

- $41 \%$-a nyilatkozott úgy, hogy a túlélés érdekében a rezsikiadásokat halmozza fel,

- a megkérdezettek $24 \%$-ának a fütésszámla kifizetése okozott nagy nehézséget, sokan közülük csak egy helyiséget fütöttek (forrás: saját adatbázis).

\section{Jövőbeni változások}

A nemzeti köznevelésröl szóló 2011. évi CXC törvény 8. § (2) bekezdése alapján 2015. szeptember 1. napjától a gyermek abban az évben, amelynek augusztus 31. napjáig a harmadik életévét betölti, a nevelési év kezdő napjától legalább napi négy órában óvodai foglalkozáson vesz részt. A Biztos Kezdet Gyerekházaknak reagálniuk kell, a jelenlegi 0-5 évröl 0-3 évre, azaz alacsonyabb életkorú gyermekek ellátására kell a figyelmet fordítaniuk, fö feladat a bölcsődére, óvodára való felkészítés lesz. 
Az NRSZH 2015. február 25. napján Szécsényben megtartott tájékoztatója szerint a közeljövőben jelentősen módosul a szakmai szabályozás is, a tervek szerint:

- az ellátott gyermekek 50\%-a RGYK-ra jogosító határozattal kell, hogy rendelkezzen, jelenleg nincs konkrét szabály a mértékre

- az ellátottak számára a nyitva tartás napi 4 óráról 5 órára emelkedik

- az ellátottak heti jelenlétét 2-3 alkalomról 5 alkalomra kell növelni

- a havi egy közösségi rendezvény helyett havi kettő megtartása lesz előírás (Kánnai, 2015).

\section{Zárógondolatok}

\section{Szakpolitikai jövőkép}

Az Emberi Erőforrások Minisztériumának Szociális ügyekért és Társadalmi Felzárkózásért felelős államtitkára és a kormányszóvivő 2015. január 22-én a Monori Gyerekházban tartott sajtótájékoztatót. Az államtitkár hangsúlyozta: a felzárkózási stratégia egyik alapeleme, hogy a gyerekek már életük első napjaiban olyan segítséget, támogatást kapjanak, „ami megakadályozza a hátrányos helyzet öröklödő ördögi körének kialakulását” (Czibere, 2015. 01. 22.). A kormányszóvivő kiemelte: „a kormány a korábbinál is hatékonyabb és célzottabb segítséget kíván adni a családoknak és az őket segítő szakembereknek. A cél, hogy a rászoruló gyerekek minél korábban megkapják azokat a javakat és szolgáltatásokat, amelyeket nélkülöznek" (Kovács, 2015. 01. 22.) A kormány célja, hogy a hálózatot, mint a felzárkóztatás politika egyik fontos elemét megerősítse. A működési támogatás rendszerébe további gyermekházak kapcsolódjanak be.

\section{Összegzés}

A Biztos Kezdet program bevezetése során azért kapott olyan különös hangsúlyt, mert mindenképpen a helyi igényeknek megfelelő és arra épülő szolgáltatásként kellett indulnia. Így nagyon változatos szervezeti keretek között nyíltak meg az első Klubok. A kezdetekkor szinte kivétel nélkül egy már meglévő bázis intézményre és annak meglévő erőforrásaira támaszkodtak és a helyi szükségletek megfogalmazásában erősen kötődtek a korábbi szolgáltatási struktúrához (Dió, 2006). Mivel a program kiállta a próbát, sőt kivívta és megtalálta saját helyét a meglévő gyermekjóléti alapszolgáltatási rendszerben, ezért törvényszerű és szükségszerü lett, hogy önállósodjon. „Kiskamasszá" válásának ténye megmutatkozik abban, hogy az önkormányzatok érdekeltek lettek, a házak többnyire a saját arculatukra formált önálló épületekben kaptak helyet. Az állami finanszírozás és a megteremtett jogszabályi környezet lehetővé teszi a felsőfokú képzettségű főállású gyerekház vezető foglalkoztatását, és a folyamatos képzést, és esetleg új gyerekházak létrejöttét.

A helyi sajátosságok érvényesítésének következményeként Magyarországon mind a 114 Gyerekház programja más és más lett, és ez különösen fontos szerepet és egyben felelősséget is ró a megvalósító szakemberekre (Nagyné, 2006).

\section{Elérhetőség}

név: Józsefvárosi Egyesített Bölcsődék Biztos Kezdet Gyerekház

cím: 1083 Budapest, Szigetvári utca 1. szám

telefon: 06-1/210-9188; 06-1/303-1767

email: jeb@bolcsode-bp08.hu; budapest.jozsefvaros@biztoskezdet.eu

gyerekház vezető: Vargáné Pozderka Terézia 


\section{Irodalom}

Bányai Emőke (2004): Intenzív családtámogató és családmegtartó szolgáltatások. PhDdolgozat, Budapest

Bányai Emőke (2006): A biztos Kezdet modellkísérleti program tapasztalatai, kiterjesztésének lehetöségei,

URL: http://www.gyerekesely.hu/index.php?option=com_phocadownload\&view=categor y\&download=152:banyai_bk_modell_tapasztalat\&id=20:gyerekekkel-kapcsolatos-hazaiszakmai-anyagok\&ltemid=73 (letöltve: 2015.02 .10 .)

Czibere Károly (2015. január 22.): Duplájára nő a Biztos Kezdet Gyerekházak támogatása. $A$ Szociális ügyekért és a Társadalmi Felzárkóztatásért felelős államtitkárság sajtótájékoztatója Monor, 2015. január 22.

URL: http://www.kormany.hu/hu/emberi-eroforrasok-miniszteriuma/szocialis-ugyekertes-tarsadalmi-felzarkozasert-felelos-allamtitkarsag/hirek/elo-kozvetites-kormanyszovivosajtotajekoztato-czibere-karollyal, (letöltve: 2015. 03. 14.)

Csapó Benő (2002): A tudásszint mérés nemzetközi és hazai eredményei. In: Csapó Benő (2002): Az iskolai tudás. Digitális Tankönyvtár, Osiris.

URL: http://www.tankonyvtar.hu/hu/tartalom/tkt/iskolai-tudas-eloszo/ch05s02.html (letöltve: 2015. 03. 14.)

Darvas Ágnes (2011): Esélyek és lehetőségek In: Labáth Ferencné (szerk.) Hátrányos helyzetü 3-7 éves korú gyermekek integrált óvodai nevelése. A Biztos Kezdet Óvodai Program háttértanulmányai 1. kötet. Educatio Társadalmi Szolgáltató Nonprofit Kft., Budapest, 9-10.

Dió Zoltán (2006): A modellkísérleti programok monitorozásának tapasztalatai. In: Nagyné Varga llona (szerk.): Biztos Kezdet füzetek 1. Jász-Nagykun-Szolnok megye Esély Szociális Közalapítványa Regionális Szellemi Forrásközpont, Budapest.

ENSZ Egyezmény a gyermek jogairól (1989)

EUROPEAN COMMISSION (2010): Communicaion from the commission EUROPE 2020 a strategy for smart, sustinable and inclusive growth, Brussels.

URL: http://www.mszoe.hu/index.php?oldal=alap.php\&fid=155\&id=372

Herczog Mária(2008):Akoraigyermekkorifejlődéselösegítése.In:Fazekas Károly, KöllöJánosés VargaJúlia(szerk.)Zöldkönyvamagyarközoktatásmegújításáért, KiadóECOSTAT,Budapest. URL: http://dok.biztoskezdet.info/index.php?mod=1\&id=6

Kánnai Magdolna (2015): Biztos Kezdet Gyerekházak jogi és szakmai keretei. EMMI Gyermekesély Főosztály Információs napok,

URL: http://nrszh.kormany.hu/download/3/f8/00000/infonap_bkg_001.pdf, (letöltve: 2015. 04. 22.)

Kovács Erika (2011): „Legyen jobb a gyerekeknek!” Biztos Kezdet Programok alapelvei. In: Labáth Ferencné (szerk.) Hátrányos helyzetü 3-7 éves korú gyermekek integrált óvodai nevelése. A Biztos Kezdet Óvodai Program háttértanulmányai 1. kötet. Kiadó Educatio Társadalmi Szolgáltató Nonprofit Kft., Budapest.

Kovács Zoltán (2015. január 22.): Duplájára nő a Biztos Kezdet Gyerekházak támogatása. $A$ Szociális ügyekért és a Társadalmi Felzárkóztatásért felelős államtitkárság sajtótájékoztatója Monor, 2015. január 22.,

URL: http://www.kormany.hu/hu/emberi-eroforrasok-miniszteriuma/szocialis-ugyekertes-tarsadalmi-felzarkozasert-felelos-allamtitkarsag/hirek/elo-kozvetites-kormanyszovivosajtotajekoztato-czibere-karollyal (letöltve: 2015. 03. 14.)

KSH 2011. évi népszámlálási adatok

Nagyné Varga llona (2006, szerk.): A helyi program tervezésének elökészítésének folyamata. Biztos Kezdet füzetek 1. Jász-Nagykun-Szolnok megye Esély Szociális Közalapítványa Regionális Szellemi Forrásközpont, Budapest.

Scheer Ferencné (2007): A csecsemőkben és kisgyermekekben rejlő képességek kibontakozásának segítése a Biztos Kezdet program klubjaiban. In: Nagyné Varga llona és Fábiánné Kocsis Lenke (szerk.) Biztos Kezdet Füzetek 2. Szociális és Munkaügyi Minisztérium, Budapest.

Scheer Ferencné (2009): Biztos Kezdet Budapesten Józsefvárosban. In: Fábiánné Kocsis Lenke és Nagyné Varga llona (szerk.) Biztos Kezdet Füzetek 3. Jó gyakorlatok a Biztos Kezdet programokban Szociális és Munkaügyi Minisztérium, Budapest. 
Sure Start Programiroda (2002.) 1-5 füzetek

Szilvási Léna (2011): Nézőpontok, Elméletek, Gyakorlatok - A magyar Biztos Kezdet program előzményei és megvalósulása. In: Balázs István (szerk.) A génektöl a társadalomig: a koragyerekkori fejlődés színterei Biztos Kezdet Kötetek 1. Nemzeti Család- és Szociálpolitikai Intézet, Budapest, 28-75.

Szomor Éva (2006): Információk a modellkísérleti programokról. In: Nagyné Varga Ilona (szerk.) Biztos Kezdet füzetek 1. Jász-Nagykun-Szolnok megye Esély Szociális Közalapítványa Regionális Szellemi Forrásközpont, Budapest.

Szomor Éva (2007): Fejlődés és fejlesztés. A gyermek fejlődésének törvényszerűségei. In: Fábiánné Kocsis Lenke és Nagyné Varga llona (szerk.) Biztos Kezdet füzetek 2. Ifjúsági, Családügyi, Szociális és Esélyegyenlőségi Minisztérium, Budapest.

Úgy tetszik, hogy jó helyen vagyunk itt, népdal: Nagyszalonta, Kodály Zoltán gyűjtése, URL: http://www.magyarnota.com/nepdalok.html

Winszoc adatbázis (2015.03.18. napi adat) Józsefvárosi Polgármesteri Hivatal, Humánszolgáltatási Ügyosztály Családtámogatási Iroda

\title{
HIVATKOZOTT JOGSZABÁLYOK ÉS KORMÁNYHATÁROZATOK
}

A gyermekek védelméröl és a gyámügyi igazgatásról szóló 1997. évi XXXI. törvény

A közoktatásról szóló 1993. évi LXXIX. törvény

A nemzeti köznevelésröl szóló 2011. évi CXC törvény 2015. szeptember 1. napjától hatályos változata

A személyes gondoskodást nyújtó gyermekjóléti, gyermekvédelmi intézmények, valamint személyek szakmai feladatairól és müködésük feltételeiröl szóló 15/1998. (IV. 30.) NM rendelet

A támogató szolgáltatás és a közösségi ellátások finanszírozásának rendjéröl szóló 191/2008. (VII. 30.) Korm. rendelet

1195/2009.(XI.20.) Kormányhatározat a „Legyen jobb a gyerekeknek!” Nemzeti Stratégiáról, 9. o. 2007-2032. szóló 47/2007. (V.31.) OGY határozat végrehajtásával kapcsolatos kormányzati feladatokról (2007-2010.) szóló 1092/2007. (XI. 29.) Kormányhatározat módosításáról.

\section{HIVATKOZOTT HONLAPOK}

\author{
www.surestart.gov.uk \\ www. biztoskezdet.hu \\ www.gyerekesely.hu \\ www.nrszh.hu \\ www.nfu.hu \\ www.tankonyvtar.hu \\ www. kormany.hu \\ www.magyarnota.com \\ www.mszoe.hu
}

\section{A BIZTOS KEZDET FELHASZNÁLT DOKUMENTUMAI}

Biztos Kezdet Gyerekházak hálózatának Szolgáltatási és Szervezeti Modellje, 2009

Pályázati útmutató a korai beavatkozást középpontba helyező Biztos Kezdet Programok országos terjesztéséhez, TÁMOP 5.2.2.

Józsefvárosi Biztos Kezdet Gyerekház Dokumentációs Rendszere

A tanulmány forrását képező saját készítésű fotókon bemutatott személyek nyilatkozatban járultak hozzá a róluk készült képek e tanulmányban történő megjelenéséhez. 